Influencing and Promoting Global Peace and Security

QHorkonmsights

Quarterly Journal by Beyond the Horizon ISSG - Volume 4 Issue 2

\title{
Taking a Closer Look to Immigration Policies
}

Cihan Aydiner
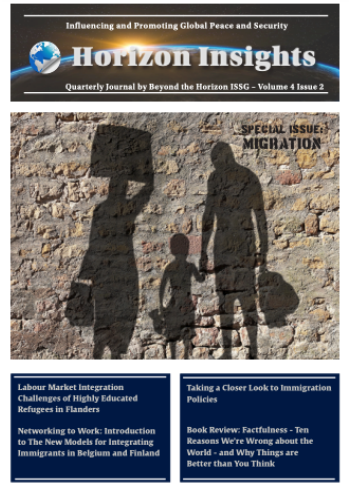

To cite this article:

Aydiner, C., (2021). Taking a Closer Look to Immigration Policies, Horizon Insights, 4(2), 20-25. https://doi.org/10.31175/hi.2021.02.03

$\Rightarrow$ For the link to this issue of the journal

https://behorizon.org/wp-content/uploads/2021/07/Horizon-Insights-2021-2.pdf

Horizon Insights Journal Homepage: https://behorizon.org/horizon-insights/

ISSN: 2593-3582 (printed), 2593-3590 (online)

Submit your article 
Cihan Aydiner*

\section{Abstract}

This article is an examination of the immigration policy formation issues in the literature. The immigration policies continue to fail today. This research provides a bird view on immigration policy issues by presenting the problematic assumptions and reasons for failures. The changing policies based on context, micro and macro-level trends, and the political goals of the governments demonstrate a consistent failure in policy formation and implementation. Also, this short article explores the role of the relationship between policymakers and social scientists in this process.

Key words: Immigrants, social policy, immigration policy, policymakers, integration.

\section{Introduction}

Policymakers and social scientists affect each other in migration-related social actions by creating laws and providing the science concerning causes of issues and overall policy implications. However, we need to look closer at this relationship since it is currently not working correctly. Cornelius and Rosenblum argued that policymakers use social science for political interests (2005). They drive and fund social sciences and create "research questions, methods, and even findings" to solve urgent problems such as the recent substantial flow of migrants to host countries (Castles, 2010, p. 1571). They are primarily interested in easy short-term answers to historically multi-dimensional issues (Castles, 2003). Also, interest groups and capital have roles in the policy process, promoting politicians' positions (Castles, 2004; Cornelius \& Rosenblum, 2005). This benefit approach especially shows itself in the labor market and the legacy problem of some immigrants. So, capitals may use irregular immigrants for the market's interests. The policymakers enjoy having controllable immigrant labels such as goodbad illegals, wanted-unwanted, or deserving-undeserving undocumented people (Chauvin \& GarcesMascarenas, 2012; Cornelius, 2005; Holmes \& Castaneda, 2016). However, sometimes playing with the labels could be difficult for policymakers because while general policies support skilled or educated immigrants, host country people could be prejudiced against their success. So, the politicians need new strategies to prevent group conflicts (Esses, Dovidio, Jackson, \& Armstrong, 2001). Though there are certain controlling or limiting factors in governments' migration policy formation process (such as international organizations), it is difficult to say if these organizations have the potential to change the interested relationship that exists in developed countries (Beckfield, 2003; Cornelius \& Rosenblum, 2005). However, some social movements and non-governmental organizations can obtain benefits for their groups. Policy-driven studies tend to produce little and generally low research. Misinformed research and scholarly actions may actually cause problems, such as one-sided policy perspectives, economic or bureaucratic errors (Castles, 2004), and negative impacts on immigrants' public opinion (Berg, 2010). The responses to migration issues such as unwanted flow mostly cause reactive approaches and a reworking of old methods instead of understanding the problem in its dynamic and specialized context (Castles, 2007). Although the immigration theorists have relinquished the simple dichotomies, the policy approach still relies on the cost-benefit dichotomy'. Some 'scientific' studies also find diversity dangerous for the harmony of receiving states (Castles, 2010). This kind of 'science' may have a danger to justify non-functional policies in the field.

\footnotetext{
" Cihan Aydiner is Non-Resident Research Fellow at Beyond the Horizon ISSG.

${ }^{1}$ Webber claims that the European Union countries breach human rights for the sake of their interests in stopping migration flows by using undemocratic countries with sticks and bones (2017).
} 


\section{Assumption of "Us" versus “Them," Examples of Migration Policies, and Reasons for their Failure}

In Western immigration policy literature, the primary assumption that underscores many migration policies is the protection of "us" at the expense of "them" (Adamson, Triadafilopoulos, \& Zolberg, 2011; Anderson, 2017; Castles, 2003). Some studies show the importance of 'other' to create or develop 'us' (Triandafyllidou, 1998). However, definitions of "us" and "them" are unclear and socially constructed. While some groups have in the past been excluded (i.e., Asians in the US), especially in times of crisis (Freeman, 1995), they may be normalized today; the inverse may also be true (i.e., Muslims in the US after 9/11) (Bloemraad, 2006). There is no consensus about what comprises "us," and the concept is not homogeneous. Some studies have attempted to show the importance of the other in creating or developing a notion of "us" (Triandafyllidou, 1998). State policies may be organized differently and practiced according to context, time, and immigrants population size (Soysal, 2012). Even historical immigrant-receiving countries of Europe such as Germany, France, and the United Kingdom do not understand policy practices in the same way2 (Koopmans, 2013). Some regional/territorial implementations of migration policies may differ from countries' rules and against civil rights (Gilbert, 2009; Varsanyi, 2011). The role of the Chicago School in the 1920s was substantial in terms of sociological immigration policies. Because sociological studies have been affected by the functionalist approach and intergroup relations of the Chicago School, assimilation theory is also influenced (Castles, 2003). In this approach, strangers are dangerous and do not belong. They should be assimilated.

However, the dichotomic classification of "us" and "others" is a limited approach. These categories are far more diverse than they appear. They are evaluated differently in cities and countries (Ariely, 2012), and the definitions change in the context of historical migration and colonized countries and new immigrants to receiving countries of the same continent, such as Europe (Bail, 2008). Moreover, there is the question of when "others" or "strangers" begin to matter to a receiving country. The size and capital of the immigration flow can widely change the perception. The most important question is: Do "they" have the potential to change "us'? When we look at the populations of immigrants in receiving countries, this begins to make sense. For example, Islam has a prominent place in European migration policy discussions, while the Spanish language is a concern in the US (Zolberg \& Woon, 1999). Immigrants' social capital also matters to receiving countries' politics (Andreouli \& Howarth, 2013). While highly educated and skilled migrants tend to be welcome in developed countries, non-elite immigrants and asylum seekers are seen as a problem and potential burden, mostly by right-wing politicians.

Above, I have presented the problematic assumptions that lie beneath migration policies. Now, I will summarize the most well-known failed migration policies. First, we must ask: what is policy failure in terms of immigration policy? Currently, it is a policy gap between the goal and the outcome. Table 1 shows the most prominent immigration policy failures as described in the literature.

\footnotetext{
${ }^{2}$ For example, while German Chancellor Merkel describes Multiculturalism as "Multikulti." She refers to the "attitude of celebrating diversity", French President Sarkozy refers to "something alien" to his country, and British Prime Minister Cameron sees the term as "state multiculturalism" (Koopmans, 2013, p. 147).
} 


\begin{tabular}{|c|c|c|c|c|}
\hline Country & Time & Policy Goal & Outcome & Literature \\
\hline Australia & Postwar & $\begin{array}{l}\text { Keep the country } \\
\text { White and British }\end{array}$ & $\begin{array}{l}\text { One of the world's } \\
\text { most diverse societies, } \\
\text { with immigrants from } \\
\text { over } 100 \text { countries }\end{array}$ & $\begin{array}{l}\text { Castles et al., 1988; } \\
\text { Castles, 2003, p. } 25\end{array}$ \\
\hline Germany & 1955-1973 & $\begin{array}{l}\text { Guest worker recruit- } \\
\text { ment to provide for } \\
\text { the temporary needs } \\
\text { of the labor market; } \\
\text { then return to home } \\
\text { country }\end{array}$ & $\begin{array}{l}\text { With the economic } \\
\text { downturn of } 1973, \\
\text { family reunions in- } \\
\text { creased, ethnic com- } \\
\text { munities developed, } \\
\text { and Germany became } \\
\text { multicultural }\end{array}$ & $\begin{array}{l}\text { Castles et al., 1984; } \\
\text { Castles, 2003, p. } 25\end{array}$ \\
\hline $\begin{array}{l}\text { France, } \\
\text { The Netherlands and } \\
\text { Britain }\end{array}$ & Post-imperialism & $\begin{array}{l}\text { Migration and citizen- } \\
\text { ship policies designed } \\
\text { to maintain political } \\
\text { and economic spheres }\end{array}$ & $\begin{array}{l}\text { Large-scale migration } \\
\text { and ethnic diversity }\end{array}$ & Castles, 2004, p. 205 \\
\hline Europe & Recent & $\begin{array}{l}\text { Immigration restric- } \\
\text { tion }\end{array}$ & $\begin{array}{l}\text { Profitable internation- } \\
\text { al business for human } \\
\text { smugglers }\end{array}$ & Castles, 2004, p. 207 \\
\hline Western Europe & The $1990 \mathrm{~s}$ & $\begin{array}{l}\text { National and regional } \\
\text { measures to reduce } \\
\text { immigration and } \\
\text { the entry of asylum } \\
\text { seekers }\end{array}$ & $\begin{array}{l}\text { The rapid growth } \\
\text { of a transnational } \\
\text { migration industry; } \\
\text { rather than stopping } \\
\text { immigration, the mea- } \\
\text { sures created business } \\
\text { opportunities for } \\
\text { new multinational } \\
\text { enterprises, both legal } \\
\text { and illegal }\end{array}$ & Portes, 1997, p. 818 \\
\hline USA & 1986 & $\begin{array}{l}\text { US Immigration } \\
\text { Reform and Control } \\
\text { Act (IRCA) designed } \\
\text { to curtail illegal } \\
\text { migration and reduce } \\
\text { entries }\end{array}$ & $\begin{array}{l}\text { The upsurge in immi- } \\
\text { gration, both legal and } \\
\text { illicit; approximately } \\
2.7 \text { million aliens } \\
\text { obtained the legal } \\
\text { immigrant status }\end{array}$ & $\begin{array}{l}\text { Portes, } 1997, \text { p. } 818 ; \\
\text { Castles, } 2004 \text {, p. } 205\end{array}$ \\
\hline USA & 1940-1964 & $\begin{array}{l}\text { Stop illegal entry } \\
\text { and employment of } \\
\text { migrant workers; } \\
\text { Mexican workers } \\
\text { officially recruited for } \\
\text { agriculture and other } \\
\text { sectors }\end{array}$ & $\begin{array}{l}\text { This program was } \\
\text { terminated in } 1964, \\
\text { but labor demand } \\
\text { remained high, and } \\
\text { large-scale illegal } \\
\text { entry continued }\end{array}$ & Castles, 2004, p. 205 \\
\hline USA & 1994 & $\begin{array}{l}\text { In response to the } \\
\text { failure of the IRCA, the } \\
\text { Clinton administra- } \\
\text { tion announced "Op- } \\
\text { eration Gatekeeper;" } \\
\text { US Immigration and } \\
\text { Naturalization Service } \\
\text { (INS) introduced } \\
\text { double steel fences, } \\
\text { helicopters, search- } \\
\text { lights, and high-tech } \\
\text { equipment along the } \\
\text { US-Mexico border }\end{array}$ & $\begin{array}{l}\text { The number of } \\
\text { agents patrolling the } \\
\text { border doubled; the } \\
\text { INS budget tripled } \\
\text { from } 1994 \text { to } 2000 \text {, } \\
\text { reaching } \$ 5.5 \text { billion; } \\
\text { no decline in illegal } \\
\text { border crossings and } \\
\text { California agricul- } \\
\text { ture experienced no } \\
\text { shortage of migrant } \\
\text { labor; the number of } \\
\text { people dying as they } \\
\text { attempted to cross the } \\
\text { border increased from } \\
23 \text { in } 1994 \text { to } 499 \text { in } \\
2000 ; \text { the average cost } \\
\text { of hiring "coyotes" } \\
\text { (human smugglers) } \\
\text { rose from } \$ 143 \text { to } \\
\$ 1,500 \text { in six years }\end{array}$ & Cornelius, 2001, 2005 \\
\hline
\end{tabular}


So, why do migration policies regularly fail? In addition to problematic, short term, interest-oriented relationships between policymakers and social scientists, there are additional explanations outlined in the literature. Portes described policy failures as the unwanted outcomes of social practice (1997). According to Anderson, "migration policies fail because they are about migration" (2017, p. 1528). Policymakers believe that migration can be stopped through legal means, so they often ignore migration's social dynamics and their links to broader social topics such as social transformation and inequality (Castles, 2003). Also, they tend to take economic considerations into account while creating migration policies. Even Australia and Canada, which historically human capital oriented countries, follow this trend by changing their selection policies following the job market needs (Akbari \& MacDonald, 2014). Although host countries tend to be powerful, their short-term policies do not consider the inherent characteristics of migration and the entire process from the determination to move from the homeland to post-migration generations' experiences. Therefore, likely failures can sometimes be invisible in the short term (Castles, 2004).

Policymakers and scholars concerned with migration often see it as abnormal and inherently problematic and seek strategies to reduce movements. By contrast, my starting point is the assumption that human mobility is a normal part of social life. At times of rapid change, such as the current epoch of accelerated globalization, international migration tends to grow in volume and to become increasingly important as a factor helping to reshape societies. Therefore, migration should be seen not just as a result of change nor a cause of change but as an integral part of social transformation processes. 


\section{References}

Adamson, F. B., Triadafilopoulos, T., \& Zolberg, A. R. (2011). The Limits of the Liberal State: Migration, Identity and Belonging in Europe. Journal of Ethnic and Migration Studies, 37(6), 843-859. Retrieved from <Go to ISI>://WOS:000290672100001. doi:10.1080/1369183x.2011.576188

Akbari, A. H., \& MacDonald, M. (2014). Immigration Policy in Australia, Canada, New Zealand, and the United States: An Overview of Recent Trends. International Migration Review, 48(3), 801-822. Retrieved from < Go to ISI>://WOS:000342844800008. doi:10.1111/imre.12128

Anderson, B. (2017). Towards a new politics of migration? Ethnic and Racial Studies, 40(9), 1527-1537. Retrieved from <Go to ISI>://WOS:000402818200015. doi:10.1080/01419870.2017.1300297

Andreouli, E., \& Howarth, C. (2013). National Identity, Citizenship and Immigration: Putting Identity in Context. Journal for the Theory of Social Behaviour, 43(3), 361-382. Retrieved from <Go to ISI>:// WOS:000323847600006. doi:10.1111/j.1468-5914.2012.00501.x

Ariely, G. (2012). Globalization, immigration and national identity: How the level of globalization affects the relations between nationalism, constructive patriotism and attitudes toward immigrants? Group Processes \& Intergroup Relations, 15(4), 539-557. Retrieved from <Go to ISI>://WOS:000305836900007. doi:10.1177/1368430211430518

Aydiner, C. and Rider, E. (2021). Migration policies and practices at job market participation: perspectives of highly educated Turks in the US, Canada and Europe. International Journal of Sociology and Social Policy. https://doi.org/10.1108/IJSSP-02-2021-0044

Bail, C. A. (2008). The configuration of symbolic boundaries against immigrants in Europe. American Sociological Review, 73(1), 37-59. Retrieved from <Go to ISI>://WOS:000256633700003. doi:10.1177/000312240807300103

Beckfield, J. (2003). Inequality in the world polity: The structure of international organization. American Sociological Review, 68(3), 401-424. Retrieved from <Go to ISI>://WOS:000222054100005. doi:10.2307/1519730

Berg, J. A. (2010). RACE, CLASS, GENDER, AND SOCIAL SPACE: Using an Intersectional Approach to Study Immigration Attitudes. Sociological Quarterly, 51(2), 278-302. Retrieved from <Go to ISI>://WOS:000276794900005. doi:10.1111/j.1533-8525.2010.01172.x

Bloemraad, I. (2006). Becoming a citizen in the United States and Canada: Structured mobilization and immigrant political incorporation. Social Forces, 85(2), 667-695. Retrieved from <Go to ISI $>$ ://WOS:000243494000004Retrieved from https://academic.oup.com/sf/article-abstract/85/2/667/2235091?redirectedFrom=fulltext. doi:10.1353/sof.2007.0002

Castles, S. (2003). Towards a sociology of forced migration and social transformation. Sociology-the Journal of the British Sociological Association, 37(1), 13-34. Retrieved from <Go to ISI $>$ ://WOS:000181349200002. doi:10.1177/0038038503037001384

Castles, S. (2004). Why migration policies fail. Ethnic and Racial Studies, 27(2), 205-227. Retrieved from <Go to ISI>://WOS:000189026800001. doi:10.1080/0141987042000177306

Castles, S. (2010). Understanding Global Migration: A Social Transformation Perspective. Journal of Ethnic and Migration Studies, 36(10), 1565-1586. Retrieved from <Go to ISI>://WOS:000283554200003. doi:10.1080/1369183x.2010.489381

Chauvin, S., \& Garces-Mascarenas, B. (2012). Beyond Informal Citizenship: The New Moral Economy of Migrant Illegality. International Political Sociology, 6(3), 241-259. Retrieved from <Go to ISI>://WOS:000308636200002. doi:10.1111/j.1749-5687.2012.00162.x

Cornelius, W. A. (2005). Controlling 'unwanted" immigration: Lessons from the United States, 1993-2004. Journal of Ethnic and Migration Studies, 31(4), 775-794. Retrieved from <Go to ISI>://WOS:000230512100009. doi:10.1080/13691830500110017 
Cornelius, W. A., \& Rosenblum, M. R. (2005). Immigration and politics. Annual Review of Political Science, 8, 99-119. Retrieved from <Go to ISI>://WOS:000230099200006. doi: 10.1146/annurev.polisci.8.082103.104854

Esses, V. M., Dovidio, J. F., Jackson, L. M., \& Armstrong, T. L. (2001). The immigration dilemma: The role of perceived group competition, ethnic prejudice, and national identity. Journal of Social Issues, 57(3), 389-412. Retrieved from <Go to ISI $>$ ://WOS:000171685100002. doi:10.1111/0022-4537.00220

Freeman, G. P. (1995). MODES OF IMMIGRATION POLITICS IN LIBERAL DEMOCRATIC-STATES. International Migration Review, 29(4), 881-902. Retrieved from <Go to ISI>://WOS:A1995TJ02300001. doi:10.2307/2547729

Gilbert, L. (2009). Immigration as Local Politics: Re-Bordering Immigration and Multiculturalism through Deterrence and Incapacitation. International Journal of Urban and Regional Research, 33(1), 26-42. Retrieved from $\langle$ Go to WoS $>$ ://WOS:000289596300015. doi:10.1111/j.1468-2427.2009.00838.x

Holmes, S. M., \& Castaneda, H. (2016). Representing the "European refugee crisis" in Germany and beyond: Deservingness and difference, life and death. American Ethnologist, 43(1), 12-24. Retrieved from <Go to ISI>://WOS:000370638200002. doi:10.1111/amet.12259

Koopmans, R. (2013). Multiculturalism and Immigration: A Contested Field in Cross-National Comparison. In K. S. Cook \& D. S. Massey (Eds.), Annual Review of Sociology, Vol 39 (Vol. 39, pp. 147-169).

Portes, A. (1997). Immigration theory for a new century: Some problems and opportunities. International Migration Review, 31(4), 799-825. Retrieved from <Go to ISI>://WOS:A1997YK95200002. doi:10.2307/2547415

Soysal, Y. N. (2012). Citizenship, immigration, and the European social project: rights and obligations of individuality. British Journal of Sociology, 63(1), 1-21. Retrieved from <Go to ISI>://WOS:000301225600001. doi:10.1111/j.1468-4446.2011.01404.x

Triandafyllidou, A. (1998). National identity and the 'other'. Ethnic and Racial Studies, 21(4), 593-612. Retrieved from <Go to ISI>://WOS:000074817400001. doi:10.1080/014198798329784

Varsanyi, M. W. (2011). Neoliberalism and Nativism: Local Anti-Immigrant Policy Activism and an Emerging Politics of Scale. International Journal of Urban and Regional Research, 35(2), 295-311. Retrieved from <Go to ISI>://WOS:000287239900005. doi:10.1111/j.1468-2427.2010.00958.x

Webber, F. (2017). Europe's unknown war. Race \& Class, 59(1), 36-53. Retrieved from <Go to ISI>:// WOS:000404622600002. doi:10.1177/0306396817701657

Zolberg, A. R., \& Woon, L. L. (1999). Why Islam is like Spanish: Cultural incorporation in Europe and the United States. Politics \& Society, 27(1), 5-38. Retrieved from <Go to ISI>://WOS:000078625800001. doi:10.1177/0032329299027001002 